\title{
The Occurrence of Argis crassa (RATHBUn, 1899) (Decapoda: Caridea: Crangonidae) from Hokkaido, Japan.
}

\author{
TOMOYUKI KOMAI \\ Natural History Museum and Institute, Chiba
}

\begin{abstract}
KOMAI, Tomoyuki (Natural History Museum and Institute, Chiba). 1994. The Occurrence of Argis crassa (RAthBun, 1899) (Decapoda: Caridea: Crangonidae) from Hokkaido, Japan. Benthos Research, 46: 33-40.

A crangonid shrimp, Argis crassa (RATHBUN, 1899), is reported from Japan for the first time based on the specimens collected from Wakkanai and Usujiri, Hokkaido. The identification is confirmed by the comparison with the Alaskan specimens. The species is characterized by the three acute median spines on the carapace and the presence of a median carina on the first and second abdominal somites.
\end{abstract}

Introduction

Recent collections around Hokkaido, northern Japan, have revealed the occurrence of a crangonid shrimp, Argis crassa (RathBun, 1899) in sublittoral zones. The species has been known from a wide area of the northern North Pacific (RAthbun, 1904; KobJakova, 1937; 1958; B UTLER, 1980), but previous records of it from Asian waters have been restricted to the Russian territory. Since previous descriptions of this species are still inadequate in some detail, I present here a description and figures of selected parts.

The following abbreviations are used in text: CL, postorbital carapace length; HUMZ, Laboratory of Marine Zoology, Hokkaido

Received August 19, 1993: Accepted November 10, 1993
University; USNM, National Museum of Natural History, Smithsonian Institution; WFES, Wakkanai Fisheries Experimental Station.

\section{Description}

Argis crassa (RATHBUn, 1899)

(Figs. 1-3)

Nectocrangon crassa RATHBUn, 1899: 556; 1904: 142, figs. 84, 85; Brashnikov, 1907: 94, fig. 9; Deruugin and Kobjakova, 1935: 142 (list); Kobjakova, 1936: 190 (list), 191 (list), 202 (list), 225 (key), fig. 24; 1937: 140; 1955: 150, pl. 37, fig. 3; 1958: 229; MAKAROv, 1941: 132; URITA, 1942: 37; Vinogradov, 1950: 220 (key), 285, fig. 93; ZARENKOv, 1965: 1764 (list), fig. 2. 

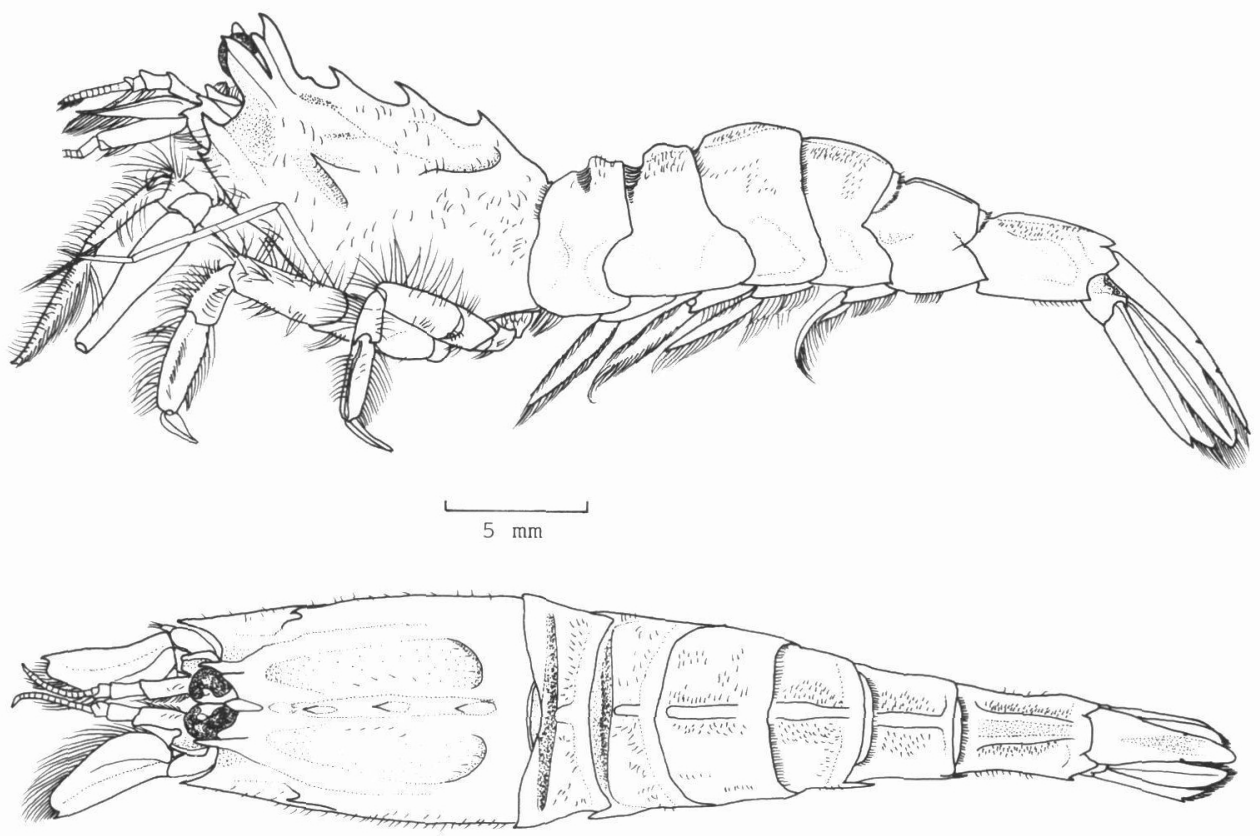

Fig. 1 Argis crassa (RAthbun, 1899). Female, CL 10.0mm (HUMZ-C 128), entire animal in lateral (upper) and dorsal (lower) views.

Argis crassa: De Man, 1920: 255 (list); Butler, 1980: 87, pl. 1D, textfig.

Not Nectocrangon crassa: KIM and PARK, 1972: 207, pl. 6, fig. 6 [=Argis hozawai (YокоYА, 1939)].

Material examined. HUMZ-C 128, 7 females (CL 10.0-10.6m), 2 males (CL $4.0,6.2 \mathrm{~mm}$ ), off Wakkanai, northern Hokkaido, depth unknown, 23 March 1987, dredge, coll. WFES; HUMZ-C 130, 15 females (CL 3.5-9.8mm), 13 males (CL 3.8$6.4 \mathrm{~mm})$, off Wakkanai, depth unknown, 24 March
1987, coll. WFES; HUMZ-C 134, off Wakkanai, depth unknown, 24 March 1987, dredge, 2 females; HUMZ-C 1105, 6 juveniles (CL 3.5-3.6mm), 1 female (CL $4.3 \mathrm{~mm}$ ), Usujiri, southern Hokkaido, 20-30m, 9 Sept. 1989, dredge, coll. T. KomaI; HUMZ-C 1120, 1 female (CL $4.5 \mathrm{~mm}$ ), Usujiri, 10-20m, 15 Nov. 1989, dredge, coll. T. K OMAI.

Comparative material. USNM 27045, 5 females (CL 9.0-10.5mm), south of Iliuliuk Harbor, Alaska, 76 m, Albatross St. 3217. 


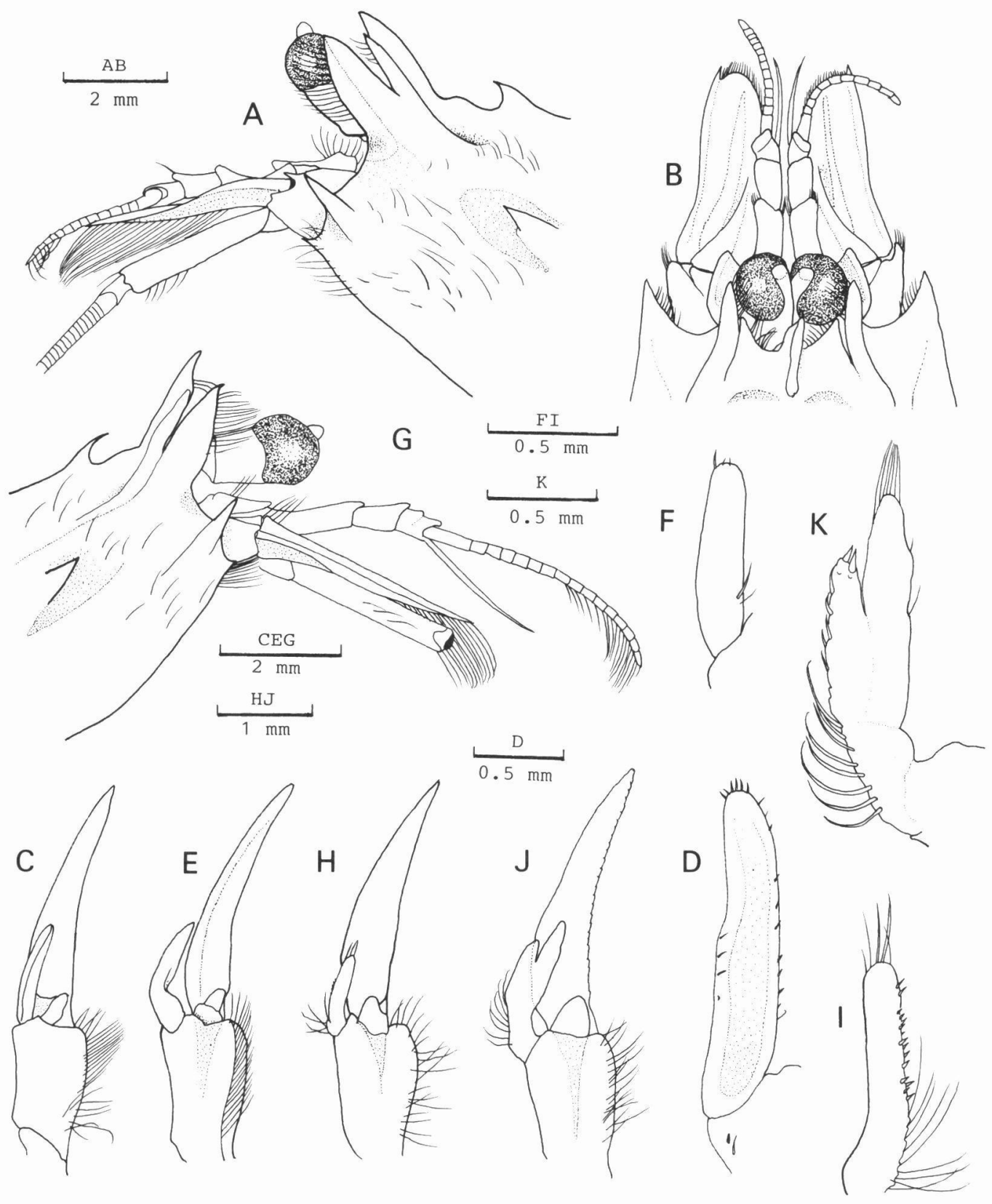

Fig. 2 Argis crassa (Rathbun, 1899). A-E, female, CL 10.3mm (HUMZ-C 128); F, young female, CL 6. 5mm (HUMZ-C 130); G-K, male, CL 6.2mm (HUMZ-C 128). A, G, anterior region of carapace and cephalic appendages, lateral; B, same, dorsal; C, H, I, left first pleopod, ventral; D, F, same, endopod, mesial; E, J, left second pleopod, ventral; K, endopod and appendix masculina of left second pleopod. Marginal setae of exopod of pleopods omitted. 
Description of adult female. Integument thick, somewhat sculptured, covered with short, dense pubescence and scattered long setae.

Carapace (Figs. 1, 2A) with anterior region strongly elevated; rostrum very short, strongly directed upward, reaching level of postorbital spine, with acute apex; postrostral median carina extending to near posterior margin of carapace, armed with 3 acute spines and usually with tubercle just behind rostral base; dorsal profile nearly straight in anterior $3 / 4$, descending just posterior to posteriormost median spine; postorbital and antennal spines set close to each other, antennal spine considerably stronger than postorbital spine; branchiostegal spine relatively small, diverging and ascending anteriorly, supported by short, blunt carina; pterygostomian spine moderately strong; hepatic spine situated at about level of anteriormost median spine; gastric depression shallow, its posterior margin bluntly delimited.

Posterior 3 thoracic sternites usually with sharp, procurved tooth respectively; in ovigerous specimen these teeth completely reduced, thoracic sternites deeply depressed; strong transverse ridge present between coxae of fourth pereopods.

Abdomen (Fig. 1) with median carina on anterior 5 somites; median carina on first somite showing as tubercle situated on posterior half of somite, those on third to fifth somites with flattened dorsal surface, not projecting beyond posterodorsal margin. Fifth and sixth somites with anterior transverse ridge delimited posteriorly by deep groove. Pleura of fourth and fifth somites armed with acute posteroventral tooth. Sixth somite 0.4 times as long as carapace, 1.4 times as long as proximal depth; paired dorsal carinae well defined, converging posteriorly, disappearing toward posterior margin of somite; posterodorsal margin produced as rounded lobe, without median sinus; posterolateral process occasionally with acute apex; posteroventral angle sharply pointed. Telson 0.7-0.8 times as long as carapace, with 2 pairs of dorsolateral spines and 1 pair of subterminal spines flanking sharply pointed apex.

Ocular peduncle (Fig. 2A, B) subcylindrical, contiguous; cornea slightly dilated; dorsal tubercle prominent, not acute, covered with short setae.

Antennule (Fig. 2A, B) with peduncle reaching middle of scaphocerite; proximal article with dorsodistal margin somewhat produced forward; stylocerite short, bluntly pointed or rounded distally, lateral margin strongly raised. Outer flagellum subequal in length to whole peduncle, distal 5 to 7 articles bearing aestetascs; inner flagellum not setose.

Scaphocerite (Fig. 2A, B) 0.4 times as long as carapace, 2.3 times as long as wide, lateral margin somewhat concave, with distolateral spine exceeding blade; ventrolateral angle of basicerite rounded; carpocerite falling slightly short of blade of scaphocerite.

Mouthparts similar to those of Argis hozawai described and figured by KoMAI and АмАоКА (1992). Third maxilliped (Fig. 3A-C) overreaching scaphocerite by most length of ultimate segment; anterodorsal margin of antepenultimate segment fringed with long setae; distal 2 segments flattened, thickly setose; ultimate segment 5.2 times as long as wide, terminating in small corneous spine directed upward, mesial surface with assemblage of several stout spines.

First pereopod (Fig. 3D) exceeding scaphocerite by length of $1 / 3$ of chela; merus (Fig. 3F) armed with anterodorsal subdistal spine, ventral surface unarmed; carpus with ventrolateral spine; palm (Fig. 3E) 3.3-3.6 times as long as wide, cutting edge of palm obliquely transverse; fixed finger broadly triangular. Second pereopod (Fig. 3G) slender, reaching beyond scaphocerite by length of chela; dactyl about 0.4 times as long as palm; cutting edges of chela (Fig. $3 \mathrm{H}$ ) with spinules. Third pereopod (Fig. 3I) slender, overreaching scaphocerite by length of dactyl and half of propodus; dactyl 0.4 


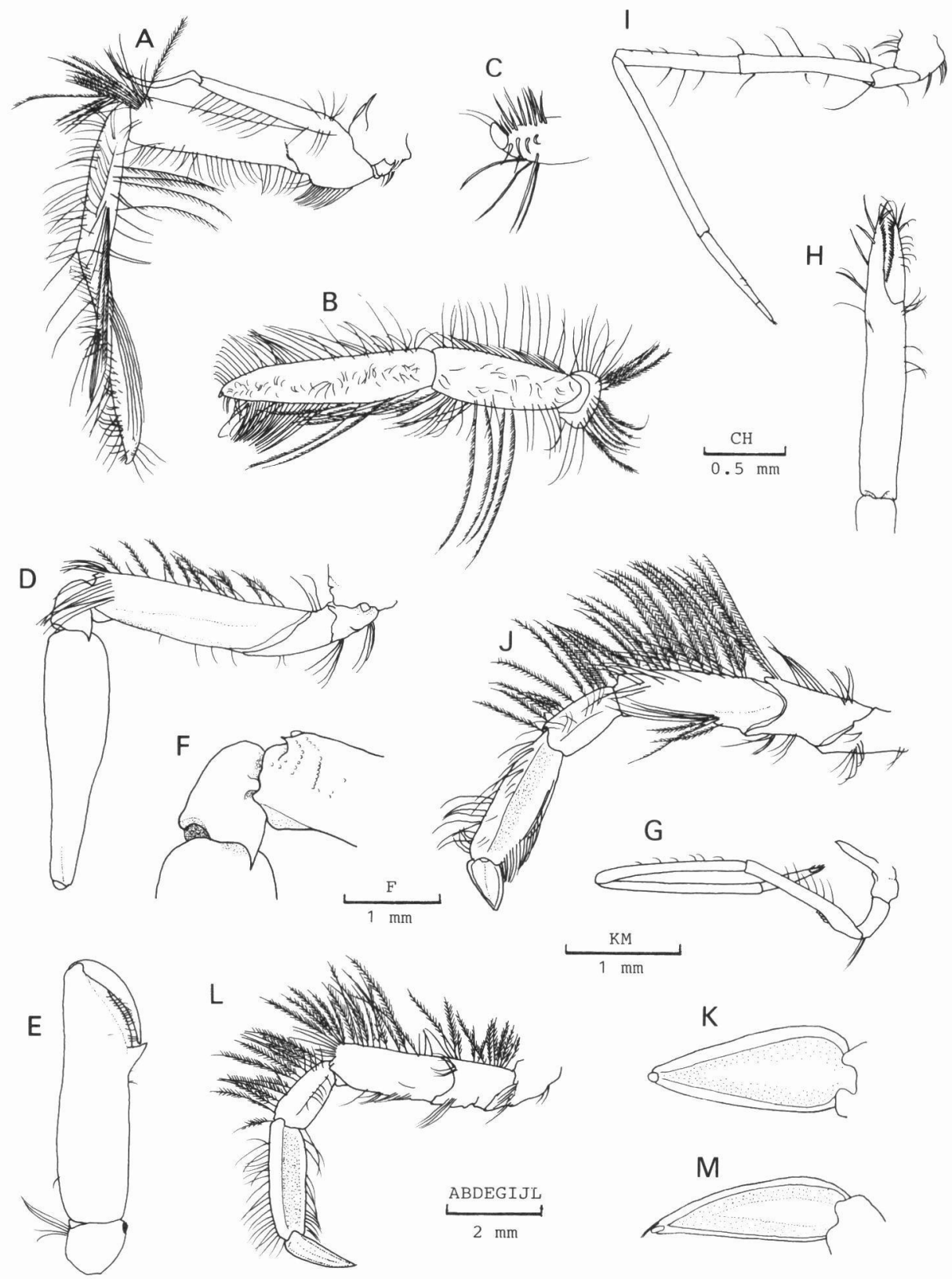

Fig. 3 Argis crassa (RAthbun, 1899), female, CL 10.3mm (HUMZ-C 128). Left thoracic appendages. A, third maxilliped, lateral; B, same, distal 2 segments, dorsal; C, same, apex of ultimate segment, lateral; D, first pereopod, lateral; E, same, chela, dorsal; F, same, carpus and distal part of merus, lateral, setae removed; G, second pereopod, lateral; H, same, chela, lateral; I, third pereopod, lateral; J, fourth pereopod, lateral; K, same, dactyl, lateral; L, fifth pereopod, lateral; M, same, dactyl, lateral. 
times as long as propodus. Fourth pereopod (Fig. 3J) stout, setiferous, slightly falling short of scaphocerite; flexor margin of carpus without setae; propodus with 2 ridges on dorsal surface, lateral face somewhat concave; dactyl (Fig. 3K) spatulate, about 0.6 times as long as propodus, 2.5 times as long as deep, terminating in corneous spine inserted between 2 unequal lobes, dorsal lobe usually with tuft of setae. Fifth pereopod (Fig. 3L) similar to fourth structurally, considerably shorter, reaching anterior margin of carapace by tip of dactyl; dactyl (Fig. $3 \mathrm{M})$ more slender than that of fourth, 3.2 times as long as deep.

Pleopods (Fig. 2C, E) without appendix internae. First pleopod (Fig. 2C, D) with endopod less than half length of exopod, mesial surface longitudinally sulcate, dorsal and terminal margins with sparse spinules. Second (Fig. 2E) to fifth pleopods with endopods somewhat constricted at proximal $2 / 5$, then curved outward. Endopod of uropod (Fig. 1) reaching tip of telson; exopod slightly falling short of tip of telson, with lateral margin nearly straight, ending posteriorly in acute spine.

Description of young female. Young females differ from adult females as follows.

Eye relatively larger, dorsal tubercle more prominent.

Dactyls of last 2 pairs of pereopods much narrower.

Endopods of pleopods developed with growth; endopod of first pleopod (Fig. 2F) without marginal spinules.

Description of male. The available material indicates that males are much smaller than females (see "Material examined") in A. crassa, as usual in the Crangonidae (BUTLER, 1980). Males differ from females of same size in the following respects.

Outer antennular flagellum distinctly longer than antennular peduncle (Fig. 2G), distal 8 to 10 articles bearing aestetascs.
Endopod of first pleopod (Fig. 2H, I) slightly curved, mesial margin proximally with long setae and distally with many spinules arranged in irregular rows; distal margin with several long setae. Endopod of second pleopod (Fig. 2J, K) about half length of exopod, with setae on distal margin; appendix masculina stout, falling far short of distal end of endopod, with several curved spines on mesial surface, distal margin with 2 or 3 stout spines.

Coloration. The description given below is based on a living female specimen collected from Usujiri.

Entire animal milky in general. Carapace with narrow transverse brown bands across posterior branchial region through dorsoposterior margin. Posteroventral portion of each second and third abdominal somites colored with brown; sixth abdominal somite pale brown, with posterior part darker (except posterolateral process); telson and uropods with brown transverse band somewhat posterior to midlength. Cornea of eye gray. Scaphocerite with 4 black spots on lateral margin. Third maxilliped with distal part of antepenultimate segment to proximal part of ultimate segment dark brown. First pereopod with proximal $1 / 3$ of chela and entire carpus pale brown. Meri of posterior 2 pairs of pereopods with broad pale brown bands.

Distribution. Aleutian Islands (RATHBUN, 1904) to San Juan Islands (ButLeR, 1980); Sea of Okhotsk (Brashnikov, 1907); Sea of Japan (DerJugin \& KoBjaKova, 1935); southern Kurile Islands (KOBJAKOVA, 1958); Wakkanai, northern Hokkaido, and Usujiri, southern Hokkaido, Japan (present study).

\section{Discussion}

The present specimens from two localities around Hokkaido, northern Japan, agree in general with the previous descriptions and 
figures of Argis crassa given by RATHBUN (1904) and ButLer (1980), who dealt with the Eastern Pacific specimens, except for a somewhat concave lateral margin of the scaphocerite contrary to straight or slightly convex. Five female specimens of $A$. crassa from Alaska were available to me for comparison. In fact, the lateral margin of the scaphocerite is nearly straight in Alaskan specimens. In other respects, however, I could not find any significant differences that justify the recognition of the Japanese population as either subspecific or specific taxon.

Three median spines on the carapace other than one tubercle just behind the rostrum distinguishes Argis crassa from all but three species of the 10 recognized species of the genus. These three species are as follows: A. alaskensis (KIngsley, 1882) from the eastern Pacific; $A$. levior (RAthBun, 1902) from the eastern Pacific; and $A$. sadoensis (Үокоча, 1933) known only from off Sado Island, Sea of Japan. Argis crassa is distinguishable immediately from $A$. alaskensis and $A$. levior in possession of a distinct median carina on the second to fourth abdominal somites (RATHBUN, 1904; BUtLER, 1980). The original description of $A$. sadoensis by $\mathrm{Y}$ OKоY A (1933) is too short to allow adequate evaluation of its specific status, but some differences between $A$. crassa and $A$. sadoensis can be detected as follows: the hepatic spine is situated more posteriorly in $A$. crassa than in $A$. sadoensis; the posterior two median spines on the carapace are acute in $A$. crassa, rather than showing spiniform tubercles as in $A$. sadoensis; the first abdominal somite possesses a blunt median carina in $A$. crassa, while this is lacking in A. sadoensis. To establish the specific status of A. sadoensis, examination of the holotype and additional material from the type-locality is needed strongly.

The specimens from Usujiri were dredged on volcanic pebbles at depths of $10-30 \mathrm{~m}$. Some specimens were kept alive in an aquarium, and showed burrowing behavior as in other congeners (Butler, 1980; Komai and AMAOKA, 1992).
The males are distinguished by differentiation of the appendix masculina when they attain $3.8 \mathrm{~mm}$ in CL. Although the sexual difference in size was apparent (the largest specimen is 10.6 $\mathrm{mm}$ in the female and $6.4 \mathrm{~mm}$ in the male), evidence of protandry could not be obtained, since both sexes were found simultaneously among small specimens with CL ranging from 3.5 to $6.4 \mathrm{~mm}$, and since no reduction of the appendix masculina accompanying growth was recognized.

\section{Acknowledgments}

My thanks are due to the technical staff of the Usujiri Marine Biological Laboratory, Faculty of Fisheries, Hokkaido University, particularly to Mr. K. NomURA, for his help to collect a part of the material. I wish to express my sincere gratitude to Dr. B. KENSLEY of the USNM for arranging the loan of Alaskan specimens of A. crassa. I also thank Dr. A. B. Williams of the USNM and two anonymous reviewers for valuable comments on the manuscript.

\section{Literature Cited}

Brashnikov, V., 1907. Materiali po fauni Russkikh vostotshikh morei, sovrannie shkhunoyu "Storoz" vi 1899-1902. [Materials on the fauna of Russian Eastern Sea collected by the schooner "Storoz" during the year 1899-1902]. Zap. Imp. Akad. Nauki, 20: 1-185, pls. 1, 2, 1 map.

Butler, T. H. , 1980. Shrimps of the Pacific coast of Canada. Can. Bull. Fish. Aquat. Sci., 202: 1-280. Government of Canada Fisheries and Oceans, Ottawa.

De Man, J. G., 1920. The Decapoda of the Siboga Expedition, IV: Families Pasiphaeidae, Stylodactylidae, Hoplophoridae, Nematocarcinidae, Thalassocaridae, Pandalidae, Psalidopodidae, Gnathophylli dae, Processidae, Glyphocrangonidae, and Crangonidae. Siboga-Exped., 39a3: 1-318, 
pls. 1-25.

Deruugin, K. M., and S. Kobjakova, 1935. Zur Dekapodenfauna des Japanischen Meeres. Zool. Anz., 112: 141-147.

KIM, H. -S. and K. -B. PARK, 1972. Faunal studies on the macrurans in Korea. Floral Studies on Some Taxa of Plants and Faunal Studies on Some Taxa of Animals in Korea, pp. 185-222, pls. 1-6. Ministry of Science and Technology, Korea. (in Korean with English summary)

KoBJAKova, Z. I., 1936. Zoogeograficheskii obzor fauny Decapoda Okhotskogo i Japonskogo Morei. [Zoogeographical survey of the Decapoda fauna from the Okhotsk and Japanese Seas]. Trudy Leningr. Obshch. Estest., 65: 185-228.

Kobjakova, Z. I., 1937. Desyatinogie raki (Decapoda) Okhotskogo i Japonskogo Morei. [Systematic review of the Decapoda of the Okhotsk and Japanese seas]. Uchen. Zap. Leningr. Univ., 15: 93-154. (with German summary)

Kobjakova, Z. I., 1955. Otryad Decyatubigue raki-Decapoda [Order Decapoda]. In E. N. Pavlovskii (ed. ), Atlas bespozvonochnykh dalinevostochynykh morei SSSR, pp. 146157, pls. 35-41. Akademii Nauk SSSR, Leningrad, Moscow.

Kobjakova, Z. I., 1958. Desyatinogie raki (Decapoda) rayona yuzhykh Kurilskikh Octrovov. [Systematic review of the Decapoda from the Southern Kurile Islands]. Issled. Dalinevost. Morei SSSR, 5: 220-248.

Komai, T. and K. АмaокA, 1992. Redescription of Argis hozawai (Yokoya, 1939) from northern Japan (Crustacea, Decapoda, Crangonidae). Proc. Jap. Soc. Syst. Zool., 48: 24-35.

Makarov, V. V., 1941. Fauna Decapoda Beringova i Chukotskogo morei. [The decapod Crustacea of the Bering and the Chukchees Seas]. Issled. Dalinevost. Morei SSSR, 1: 111-163. (with English summary)
Rathbun, M. J., 1899. List of Crustacea known to occur on and near the Pribilof Islands. In, Jordan, D. S., et al., The fur seals and fur seal islands of the North Pacific Ocean, 3: 555-557. U. S. Government Press, Washington.

Rathbun, M. J., 1904. Decapod Crustaceans of the northwest coast of North America. Harriman Alaska Exped., 10: 1-190, pls.1-10.

VinOGRADOv, L. G., 1950. Opredelitel'krevetok, rakov i krabov Dal'nego Vostoka. [A key to the shrimps, lobsters and crabs of the Far East]. Izv. TINRO, 33: 179-358, pls. 1-53.

ҮокочА, Y., 1933. On the distribution of decapod crustaceans inhabiting the continental shelf around Japan, chiefly based upon the materials collected by S. S. Soyo-Maru, during the year 1923-1930. J. Coll. Agr. Tokyo Imp. Univ., 12: 1-226.

Zarenkov, N. A., 1965. Reviziya rodov Crangon Fabricius i Sclerocrangon G. O. Sars (Decapoda, Crustacea). [Revision of the genera Crangon Fabricius and Sclerocrangon G. O. Sars]. Zool. Zh., 44(12): 1761-1775.

TомочUKI КомаI

Natural History Museum and Institute, Chiba 955-2 Aoba-cho, Chuo-ku, Chiba 260, Japan

駒井智幸：ミットゲクロザコエビ（新称）（十脚目： コエビ下目：エビジャコ科）の日本からの初記録。

北海道北部稚内沖と同南部臼尻から採集された標本 に基づき，エビジャコ科クロザコエビ属のArgis crassa（RATHBUN, 1899)（新称ミットゲクロザコエ ビ）を報告した．同定に当たっては, 原記載地に近い アラスカ産の標本と比較検討した，本種は，頭胸甲に 3 本の正中棘を持つグループに入るが, 第 1 腹節に顕 著な正中隆起を持っことで，近縁種から識別される。 また，本種はロシア沿岸を含む北部北太平洋の広い範 囲から記録されていたが, 本研究により, 日本沿岸で の分布が確認された。 